\title{
Changed Number of the Collection of Permian Ammonoids from Novaya Zemlya Housed in the Cited Collection Repository of the Borissiak Paleontological Institute, Russian Academy of Sciences
}

\author{
T. B. Leonova \\ Borissiak Paleontological Institute, Russian Academy of Sciences, Profsoyuznaya ul. 123, Moscow, 117997 Russia \\ e-mail: tleon@paleo.ru \\ Received December 08, 2009
}

DOI: $10.1134 / \mathrm{S} 0031030110030160$

While curating Permian ammonoids from the Urals in the Cited Collection Repository of the Borissiak Paleontological Institute, Russian Academy of Sciences (PIN), staff discovered that the number $3638 / 165$ was used twice in the type collections described and cited by Bogoslovskaya et al. (1982) and Bogoslovskaya and Boiko (2002). Bogoslovskaya et al. (1982) used this number for a specimen figured on Pl. 7, fig. 6 Sverdrupites amundseni Nassichuk, 1970 from the Roadian of the South Island of Novaya Zemlya, while Bogoslovskaya and Boiko (2002) used this number for the holotype of Uraloceras posterum Bogoslovskaya et Boiko, 2002 (family Paragastrioceratidae) from the South Urals described on p. 36 and figured in Fig. 1g and Pl. 3, fig. 5.

Later, while describing the Permian ammonoid family Spirolegoceratidae, T.B. Leonova and O.P. Shilovsky (2007), redescribed the specimens from Collection no. 3638 housed in PIN previously identified as Sverdrupites amundseni, and gave it a new name S. bogoslovskayae Leonova et Shilovsky. They identified specimen no. 3638/165 as $S$. bogoslovskayae, and gave its measurements. A specimen figured by Bogoslovskaya et al. (1982) as PIN 3638/164 was designated as the holotype of $S$. bogoslovskayae. The holotype of $S$. bogoslovskayae was figured in two papers (Leonova, 2006; 2007).

To rectify this confusion, I suggest that number 3638 should continue to be used for the collection of Early Permian ammonoids from the Middle and South Urals (coll. by P.A. Sofronitsky, B.I. Chuvashov, and A.A. Bolotov, 1955, 1973-1975, 1997) housed in the Repository of PIN. Ammonoids from this collec- tion are described by Bogoslovskaya (1976) and Bogoslovskaya and Boiko (2002).

It is proposed to give to the collections of the Early and Middle Permian ammonoids from the South Island of Novaya Zemlya (coll. by V.A. Molin, V.P. Matveev, O.P. Timofeev, G.V. Trufanov, and L.S. Khar'yuzov in 1975-1980) number 3638a. Ammonoid specimens from this collection are figured and cited by Bogoslovskaya et al. (1982); Leonova and Shilovsky (2007); Leonova (2006, 2007).

\section{REFERENCES}

1. M. F. Bogoslovskaya, "Kungurian Ammonoids of the Central Cis-Urals," Paleontol. Zh., No. 4, 43-50 (1976).

2. M. F. Bogoslovskaya and M. S. Boiko, "The Evolution and Distribution of the Early Permian Genus Uraloceras (Ammonoidea)," Paleontol. Zh., No. 6, 31-37 (2002) [Paleontol. J. 36 (6), 598-605 (2002)].

3. M. F. Bogoslovskaya, V. I. Ustritskii, and G. E. Chernyak, "Permian Ammonoids of Novaya Zemlya," Paleontol. Zh., No. 4, 58-67 (1982).

4. T. B. Leonova, "Roadian Ammonoids in the Northern Regions of the Earth," in Evolution of the Biosphere and Biodiversity (Paleontol. Inst. Ross. Akad. Nauk, Moscow, 2006), pp. 540-551 [in Russian].

5. T. B. Leonova, "Correlation of the Kazanian of the Volga-Urals with the Roadian of the Global Permian Scale," Paleoworld 16, 246-253 (2007).

6. T. B. Leonova and O. P. Shilovsky, "Evolution of the Permian Family Spirolegoceratidae (Goniatitida, Ammonoidea)," Paleontol. Zh., No. 1, 27-36 (2007) [Paleontol. J. 41 (1), 28-38 (2007)]. 